\title{
Metaplastic breast carcinomas exhibit EGFR, but not HER2, gene amplification and overexpression: immunohistochemical and chromogenic in situ hybridization analysis
} Jorge S Reis-Filho1,2,3*, Fernanda Milanezi $2,3^{\star}$, Silvia Carvalho2,3*, Pete T Simpson4, Dawn Steele1, Kay Savage1, Maryou BK Lambros ${ }^{1}$, Emilio M Pereira ${ }^{5}$, Jahn M Nesland ${ }^{6}$, Sunil R Lakhani ${ }^{4}$ and Fernando C Schmitt²

\author{
1The Breakthrough Breast Cancer Research Centre, Institute of Cancer Research, London, UK \\ 2IPATIMUP - Institute of Molecular Pathology and Immunology, University of Porto, Porto, Portugal \\ ${ }^{3}$ Life and Health Sciences Research Institute (ICVS), School of Health Sciences, University of Minho, Braga, Portugal \\ ${ }^{4}$ Molecular \& Cellular Pathology, Mayne Medical School, University of Queensland, Queensland Institute of Medical Research and Royal Brisbane \\ and Women's Hospital, Brisbane, Australia \\ 5Laboratório Salomão \& Zoppi, São Paulo, Brazil \\ ${ }^{6}$ The Norwegian Radium Hospital, University of Oslo, Montebello, Norway \\ * Contributed equally \\ Corresponding author: Jorge S Reis-Filho, jorgerf@icr.ac.uk \\ Received: 17 Jul 2005 Revisions requested: 31 Aug 2005 Revisions received: 12 Sep 2005 Accepted: 29 Sep 2005 Published: 25 Oct 2005 \\ Breast Cancer Research 2005, 7:R1028-R1035 (DOI 10.1186/bcr1341) \\ This article is online at: http://breast-cancer-research.com/content/7/6/R1028 \\ (c) 2005 Reis-Filho et al.; licensee BioMed Central Ltd. \\ This is an Open Access article distributed under the terms of the Creative Commons Attribution License (http://creativecommons.org/licenses/by/ \\ 2.0), which permits unrestricted use, distribution, and reproduction in any medium, provided the original work is properly cited.
}

\begin{abstract}
Introduction Metaplastic breast carcinomas constitute a heterogeneous group of neoplasms, accounting for less than $1 \%$ of all invasive mammary carcinomas. Approximately $70-$ $80 \%$ of metaplastic breast carcinomas overexpress the epidermal growth factor receptor (EGFR). Human epidermal growth factor receptor (HER)2 and EGFR have attracted much attention in the medical literature over the past few years owing to the fact that humanized monoclonal antibodies against HER2 and therapies directed against the extracellular ligand-binding domain or the intracellular tyrosine kinase domain of EGFR have proven successful in treating certain types of human cancer. We investigated whether HER2 and EGFR overexpression was present and evaluated gene amplification in a series of metaplastic breast carcinomas.
\end{abstract}

Method Twenty-five metaplastic breast carcinomas were immunohistochemically analyzed using a monoclonal antibody (31G7) for EGFR and two antibodies for HER2 (Herceptest and CB11) and scored using the Herceptest scoring system. Gene amplification was evaluated by chromogenic in situ hybridization using Zymed Spot-Light EGFR and HER2 amplification probe.
The results were evaluated by bright field microscopy under $40 \times$ and $63 \times$ objective lenses.

Results Nineteen (76\%) metaplastic breast carcinomas exhibited EGFR ovexpression, and among these EGFR amplification (defined either by large gene clusters or $>5$ signals/nucleus in $>50 \%$ of neoplastic cells) was detected in seven cases (37\%): three carcinomas with squamous differentiation and four spindle cell carcinomas. One case exhibited HER2 overexpression of grade $2+(>10 \%$ of cells with weak to moderate complete membrane staining), but HER2 gene amplification was not detected.

Conclusion Metaplastic breast carcinomas frequently overexpressed EGFR, which was associated with EGFR gene amplification in one-third of cases. Our findings suggest that some patients with metaplastic breast carcinomas might benefit from novel therapies targeting EGFR. Because most metaplastic breast carcinomas overexpress EGFR without gene amplification, further studies to evaluate EGFR activating mutations are warranted. 


\section{Introduction}

In recent years, the family of epidermal growth factor receptors (EGFRs) or ERBB receptors has attracted great attention in the literature [1]. This family includes four tyrosine kinase receptors: EGFR (HER1/c-erbB1), human epidermal growth factor receptor (HER)2/neu (c-erbB2), HER3 (c-erbB3) and HER4(c-erbB4). All members of this family are characterized by an extracellular ligand-binding region, a single membrane spanning region, and a cytoplasmic tyrosine kinase containing domain [1]. Although expression of the four members of the ERBB family has been studied in several types of human tumours [1], only EGFR and HER2 have been proven to play major roles in different histological types of breast cancer [112]. Thus far, only these two receptors have successfully been targeted as therapy for lung [13-17] and breast cancer $[18,19]$.

EGFR was the first tyrosine kinase receptor to be directly linked with human cancer. The EGFR gene maps to $7 p 11.2-$ p2 and encodes a $170 \mathrm{kDa}$ transmembrane protein [1]. EGFR gene amplification has been described in oligodendrogliomas [20], glioblastomas [21], lung carcinomas [13,14,22], gastric carcinomas [23] and, recently, breast carcinomas [8,24,25]. The HER2 gene maps to chromosome 17q21 and encodes a $185 \mathrm{kDa}$ glycoprotein. It is reported to be amplified and overexpressed in several types of human tumours, including about $30 \%$ of all breast carcinomas $[1,18,19]$. Most importantly, in recent years EGFR tyrosine kinase inhibitors and humanized monoclonal antibodies against HER2 have received US Food and Drug Administration approval and are currently being tested in patients with lung and breast cancer.

Data on the response of patients with lung cancer have demonstrated that approximately $10-15 \%$ of patients with EGFRpositive lung carcinomas have a dramatic response to EGFR tyrosine kinase inhibitors [15-17,22]. Interestingly, response was linked to the presence of an activating somatic mutation targeting the tyrosine domain of EGFR [15-17]. In addition, Cappuzzo and coworkers [22] demonstrated that EGFR amplification is a strong predictor of response to EGFR tyrosine kinase inhibitors. Unlike EGFR activating mutations, EGFR amplifications also exhibited a statistically significant association with survival [22].

Although HER2 gene amplification and protein overexpression have been extensively studied in breast cancer, data on EGFR amplification in breast cancer are limited. HER2 overexpression has been identified in $87 \%$ and $27 \%$ breast carcinomas with EGFR overexpression [7] and gene amplification [8], respectively. Interestingly, EGFR and HER2 coexpression in breast cancer was recently associated with reduced overall survival (OS) and disease-free survival (DFS) [7].

Our group and others have demonstrated that 'basal-like' breast carcinomas and metaplastic breast carcinomas
(MBCs) consistently overexpress EGFR but usually lack HER2 overexpression [12,26]. However, the presence of EGFR gene amplifications have not been systematically analyzed in a series of MBCs. The aims of the present study were threefold: to analyze the presence of EGFR gene amplifications in MBCs; to correlate the presence of EGFR amplifications with EGFR immunohistochemical overexpression; and to assess HER2 overexpression in MBCs.

\section{Materials and methods}

\section{Metaplastic breast carcinoma samples}

Cases of MBC were identified and samples retrieved from the pathology files of the Royal Marsden Hospital (London, UK), the Institute of Molecular Pathology and Immunology, University of Porto (Porto, Portugal), and the Norwegian Radium Hospital (Montebello, Norway). The project was approved by the local ethics committees.

Cases of MBC were identified from the Royal Marsden from January 1980 to March 2004 by searching the electronic Hospital Information System for cases diagnosed as adenosquamous carcinoma, carcinosarcoma, metaplastic breast carcinoma, sarcomatoid carcinoma, spindle cell carcinoma and squamous cell carcinoma, as well as from the consultation files of one of the authors (SRL). Cases from the Institute of Molecular Pathology and Immunology and the Norwegian Radium Hospital were identified from the consultation files of two of the authors (JMN and FCS, respectively). All cases were initially reviewed by the contributing authors, who evaluated additional immunohistochemical markers to corroborate the diagnosis.

The cases were centrally reviewed by three of the authors (JSR-F, FM and FCS) on a multiheaded microscope and classified according to previously described criteria [27-33]. Briefly, tumours were classified as matrix producing breast carcinomas if chondroid and/or osseous matrix was observed in the absence of spindle and osteoclast giant cell components [31]. Neoplasms were classified as spindle cell carcinomas if intraductal or infiltrating ductal or squamous carcinoma of ductal origin was contiguous or subtly merged with a spindle cell proliferation of neoplastic cells, which comprised at least $50 \%$ of the tumour bulk [30]. Carcinomas with heterologous elements were defined as tumours with an intraductal or invasive carcinomatous component intimately admixed or subtly merging with a sarcomatous spindle cell component with evidence of chondroid, osseous, or rhabdomyoid differentiation [29,32]. Carcinomas with squamous differentiation were predominantly $(>50 \%)$ or completely composed of apparent squamous cell components admixed with areas of invasive ductal and/or spindle cell carcinoma, in the absence of involvement of the ovevrlying skin $[28,33]$. A median of two representative blocks from each case was selected for immunohistochemical and chromogenic in situ hybridization (CISH) analysis. 
Table 1

\begin{tabular}{|c|c|c|c|c|c|}
\hline Case & Histological type & HER2 (Herceptest ${ }^{\circledR}$ ) & HER2 (CB11) & EGFR (IHC) & $E G F R(\mathrm{CISH})$ \\
\hline 1 & Carcinoma with squamous metaplasia & - & - & $3+$ & No amp \\
\hline 2 & Carcinoma with squamous metaplasia & - & - & $3+$ & No amp \\
\hline 3 & Carcinoma with squamous metaplasia & - & - & $3+$ & No amp \\
\hline 4 & Carcinoma with squamous metaplasia & - & - & $3+$ & No amp \\
\hline 5 & Carcinoma with squamous metaplasia & - & - & $3+$ & Amp \\
\hline 6 & Carcinoma with squamous metaplasia & - & - & $3+$ & Amp \\
\hline 7 & Carcinoma with squamous metaplasia & $1+$ & - & $3+$ & No amp \\
\hline 8 & Carcinoma with squamous metaplasia & - & - & $3+$ & Amp \\
\hline 9 & Carcinoma with squamous metaplasia & - & - & $1+$ & No amp \\
\hline 10 & Spindle cell carcinoma & - & - & $3+$ & No amp \\
\hline 11 & Spindle cell carcinoma & - & - & $3+$ & No amp \\
\hline 12 & Spindle cell carcinoma & - & - & $1+$ & No amp \\
\hline 13 & Spindle cell carcinoma & - & - & $3+$ & Amp \\
\hline 14 & Spindle cell carcinoma & - & - & - & No amp \\
\hline 15 & Spindle cell carcinoma & - & - & $3+$ & Amp \\
\hline 16 & Spindle cell carcinoma & - & - & - & No amp \\
\hline 17 & Spindle cell carcinoma & - & - & $3+$ & Amp \\
\hline 18 & Spindle cell carcinoma & - & - & $3+$ & No amp \\
\hline 19 & Spindle cell carcinoma & $2+a$ & $1++^{a}$ & $3+$ & Amp \\
\hline 20 & Carcinoma with heterologous elements & - & - & $3+$ & No amp \\
\hline 21 & Carcinoma with heterologous elements & - & - & $3+$ & No amp \\
\hline 22 & Matrix producing carcinoma & - & - & $1+$ & No amp \\
\hline 23 & Matrix producing carcinoma & - & - & - & No amp \\
\hline 24 & Matrix producing carcinoma & - & - & $3+$ & No amp \\
\hline 25 & Matrix producing carcinoma & - & - & $3+$ & No amp \\
\hline
\end{tabular}

aNo HER2 gene amplification was detected by CISH. Amp, amplification; CISH, chromogenic in situ hybridization; EGFR, epidermal growth factor receptor; HER, epidermal growth factor receptor; IHC, immunohistochemistry.

\section{Immunohistochemical and chromogenic in situ hybridization analysis}

Immunohistochemistry was performed with antibodies raised against HER2 (Herceptest ${ }^{\circledR}$ (Dako, Glosatrup, Denmark), polyclonal, $1 / 10$ epitope retrieval solution (Dako) at $98^{\circ} \mathrm{C}$, prediluted; and CB11 (Novocastra, Newcastle-upon-Tyne, UK), 2 min in a pressure cooker, 1:100) and EGFR (31G7, 1:50, Zymed (South San Francisco, CA, USA)), as previously described [34]. For Her2/neu and EGFR, the Herceptest ${ }^{\circledR}$ scoring system was applied: negative $=$ no membrane staining or $<10 \%$ of cells stained; $1+=$ incomplete membrane staining in $>10 \%$ of cells; $2+=>10 \%$ of cells with weak to moderate complete membrane staining; and $3+=$ strong and complete membrane staining in $>10 \%$ of cells.
$\mathrm{CISH}$ was performed using Spot-Light amplification probes for EGFR (Zymed) and HER2 (Zymed), in accordance with the manufacturer protocol and as previously described [34]. Because the interpretation guidelines for Spot-Light EGFR and HER2 amplification probes have previously been validated $[8,34,35]$, we did not use $\alpha$-satellite probes for chromosomes 7 and 17, respectively. All cases were subjected to $\mathrm{CISH}$ for EGFR, and only those with HER2 grade 2+ or 3+ positivity were subjected to $\mathrm{CISH}$ for HER2[36]. Appropriate gene amplified breast tumour controls were included in each run. Each section was analyzed by two of the authors (FM and $\mathrm{SC}$ ) on a multiheaded microscope. Only unequivocal signals were counted. Signals were evaluated at $400 \times$ and $630 \times$, and at least 60 cells were evaluated for the presence of the EGFR probe. A given tumour was considered to be amplified for EGFR or HER2 when more than $50 \%$ of the neoplastic cells 
exhibited more than five signals per nuclei or large gene signal clusters $[8,34,36]$.

Out of the 112 cases of metaplastic breast carcinomas in our series, 25 had sufficient material in the blocks and were successfully analyzed by both immunohistochemistry and $\mathrm{CISH}$ for EGFR and HER2.

\section{Correlation between EGFR overexpression and amplification and clinicopathological parameters and survival}

Follow-up information was available for 23 out of 25 patients, with follow-up periods ranging from 5.5 to 124.3 months (median 34.6 months, mean 51.9 months). The Statview software package was used for all calculations. Correlations between categorical variables were performed using the $\chi^{2}$ test and Fisher's exact test. Correlations between continuous and categorical variables were performed with analysis of variance. DFS and OS were expressed as the number of months from diagnosis to the occurrence of an event (local recurrence/metastasis and disease-related death, respectively). Cumulative survival probabilities were calculated using the Kaplan-Meier method. Differences between survival rates were tested using the log-rank test. All tests were two-tailed, with a confidence interval of $95 \%$.

\section{Results}

Table 1 summarizes the results of the histological, immunohistochemical and CISH analyses. Briefly, 19 out of 25 (76\%) cases exhibited EGFR positivity of grade 3+. No samples showed EGFR grade 2+ positivity, whereas four cases were EGFR $1+$. Out of the 19 cases with EGFR grade 3+ expression, seven (37\%) exhibited EGFR gene amplification (Fig. 1). Three out of nine carcinomas with squamous metaplasia and four out of 10 spindle cell carcinomas had EGFR amplification, whereas no matrix producing breast carcinomas showed any amplification. Interestingly, similar numbers of EGFR signals were observed in the epithelial and in the metaplastic elements. One case exhibited HER2 grade $2+$ positivity with Herceptest $^{\circledR}$, but $H E R 2$ gene amplification was not observed (Fig. 2).

No association between EGFR overexpression or amplification and clinicopathological features was observed (Table 2). EGFR overexpression showed no association with DFS or OS. Patients with tumours harbouring EGFR amplification had a trend toward shorter DFS and OS (Fig. 3).

\section{Discussion}

In recent studies, we and others demonstrated that MBCs frequently overexpress EGFR and lack HER2 overexpression. In a previous study [26] we demonstrated that up to $83 \%$ of all MBCs show EGFR overexpression. Leibl and Moinfar [12] described positivity for EGFR in $70 \%$ of MBCs, but those authors also considered cases with grade $1+$ expression to be

\section{Figure 1}

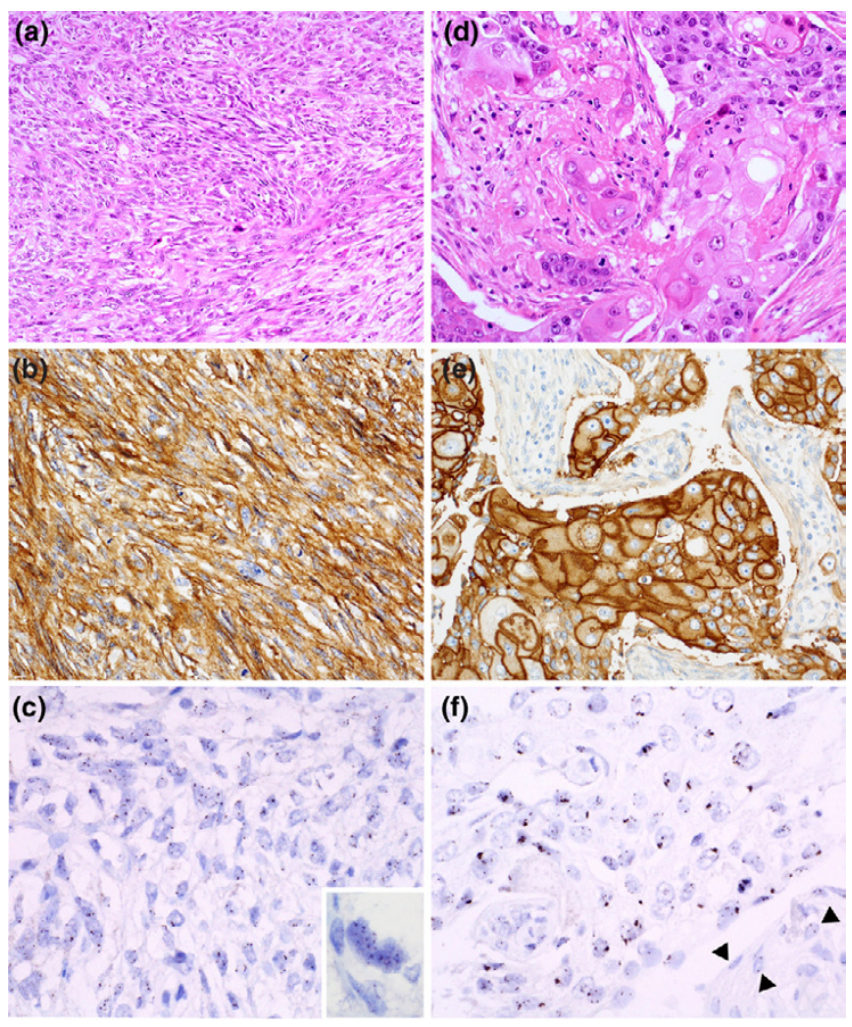

EGFR overexpression and gene amplification in MBCs. Photomicrographs of (a) a spindle cell metaplastic breast carcinoma (haematoxylin and eosin) showing (b) grade 3+ immunohistochemical positivity for EGFR and (c) EGFR gene amplification ( $>5$ signals per nucleus [CISH]). Inset in panel c: note the bizarre neoplastic cell with more than 10 copies of EGFR. (d) Breast carcinoma with squamous metaplasia (haematoxylin and eosin) with (e) EGFR grade 3+ immunohistochemical positivity. (f) $\mathrm{CISH}$ demonstrating EGFR amplification (clusters of signals in the nuclei of neoplastic cells). Note the presence of one or two signals in the nuclei of stromal cells (arrowheads). $\mathrm{CISH}$, chromogenic in situ hybridization; EGFR, epidermal growth factor receptor; $\mathrm{MBC}$, metaplastic breast carcinoma.

positive. When only grade $2+$ and $3+$ expression was considered to represent positivity, $60 \%(12 / 20)$ were positive. In the present study we demonstrated that $76 \%(19 / 25)$ of MBCs overexpressed EGFR. The differences between our findings and those of Leibl and Moinfar [12] may be related to the different antibody clones used and different antigen retrieval methods.

The mechanism underlying EGFR overexpression has not been investigated in MBCs. In the present study we demonstrated that $E G F R$ is amplified in $28 \%(7 / 25)$ of MBCs and in $37 \%(7 / 19)$ of MBCs with EGFR overexpression. Although only six cases with heterologous elements (four matrix producing carcinomas and two carcinomas with heterologous elements) were analyxed, no amplification was found in these two subtypes of MBC. Identification of areas of squamous differentiation in spindle cell carcinomas and the presence of spindle 

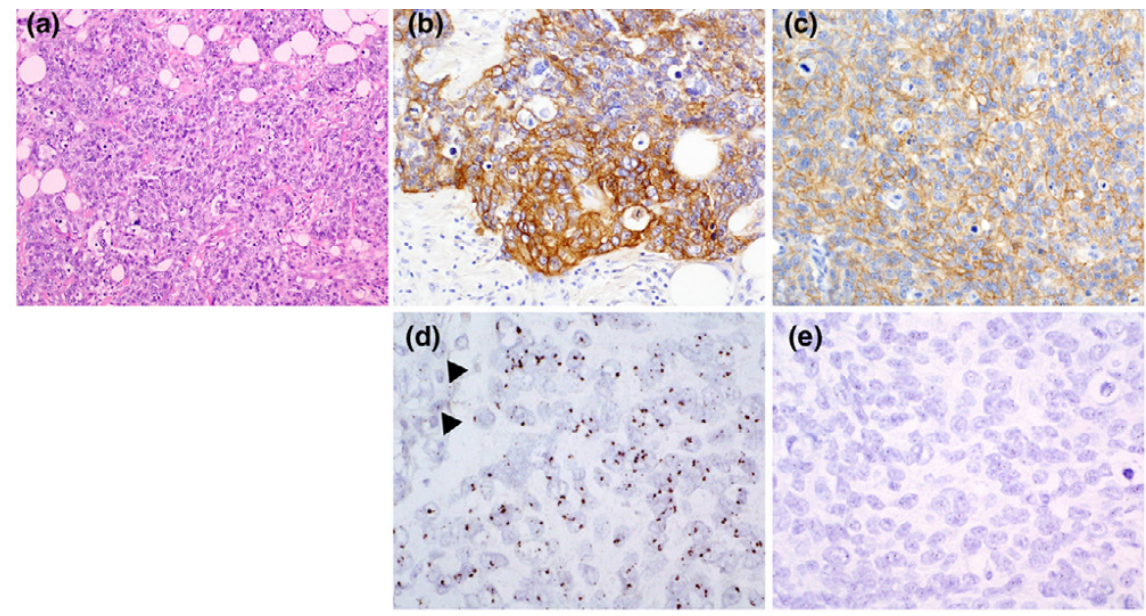

EGFR and HER2 overexpression and gene amplification in a spindle cell carcinoma. (a) Photomicrograph of a spindle cell carcinoma (haematoxylin and eosin). Immunohistochemical analysis revealed (b) EGFR grade 3+ positivity and (c) HER2 grade 2+ reactivity. (d) CISH demonstrating EGFR amplification (clusters of signals in the nuclei of neoplastic cells). Note the presence of one or two copies of EGFR in stromal cells (arrowheads). (e) CISH for HER2 gene: no amplification (2-3 gene copies/nucleus). CISH, chromogenic in situ hybridization; EGFR, epidermal growth factor receptor; HER, human epidermal growth factor receptor; MBC, metaplastic breast carcinoma.

\section{Table 2}

Summary of the associations between clinicopathological parameters and EGFR overexpression and amplification

\begin{tabular}{|c|c|c|c|c|c|c|}
\hline \multirow[t]{2}{*}{ Parameter } & \multicolumn{2}{|c|}{ EGFR IHC } & \multirow[t]{2}{*}{$P$} & \multicolumn{2}{|c|}{$E G F R \mathrm{CISH}$} & \multirow[t]{2}{*}{$P$} \\
\hline & Negative & Overexpression & & No & Amplified & \\
\hline Age (years) & $54.2(13.3)$ & $48.8(13.3)$ & $>0.05$ & $50.4(13.7)$ & $48.8(12.7)$ & $>0.05$ \\
\hline Size $(\mathrm{cm})$ & $4.0(3.2)$ & $4.4(3.1)$ & $>0.05$ & $3.8(2.9)$ & $5.9(3.9)$ & $>0.05$ \\
\hline \multicolumn{7}{|c|}{ Lympho-vascular invasion } \\
\hline No & 2 & 9 & $>0.05$ & 9 & 2 & $>0.05$ \\
\hline Yes & 2 & 9 & & 7 & 4 & \\
\hline \multicolumn{7}{|c|}{ Lymph node metastasis at diagnosis } \\
\hline No & 3 & 11 & $>0.05$ & 10 & 4 & $>0.05$ \\
\hline Yes & 1 & 5 & & 4 & 2 & \\
\hline
\end{tabular}

$\mathrm{CISH}$, chromogenic in situ hybridization; EGFR, epidermal growth factor receptor. IHC, immunohistochemistry.

cells in carcinomas with squamous metaplasia are not infrequent. In fact, in the seminal study conducted by Huvos and coworkers [32] these two subtypes of MBCs were classified under the heading 'group 1' MBCs. In addition, when EGFR is overexpressed in carcinomas with heterologous elements and matrix producing breast carcinomas, its expression appears to be more conspicuous in epithelial components (data not shown). In a recent study, Bhargava and coworkers [8] demonstrated that $6 \%(11 / 175)$ of all breast carcinomas exhibit EGFR amplification. Interestingly, one of these 11 cases was a spindle cell metaplastic carcinoma with focal squamous differentiation. Taken together, these findings suggest that EGFR overexpression and/or gene amplification are likely to play a role in carcinomas with squamous elements and spindle cell carcinomas, but perhaps not in the other subtypes of MBC.

Because the methods used by Bhargava and coworkers [8] are identical to ours, a direct comparison is feasible. Taken together, our results and those of Bhargava and coworkers indicate that EGFR amplification is statistically more prevalent in MBCs than in other types of breast carcinoma (10/174 nonmetaplastic breast carcinomas versus $8 / 26$ metaplastic breast carcinomas showed EGFR amplification; $P<0.001$ by Fisher's exact test (two sided)).

Although EGFR amplification accounted for 37\% of EGFR overexpression in the present series, the majority of cases 
Figure 3

Kaplan-Meier Cum. Survival Plot for DFS

Censor Variable: Censor DFS

Grouping Variable: EGFR overexpression

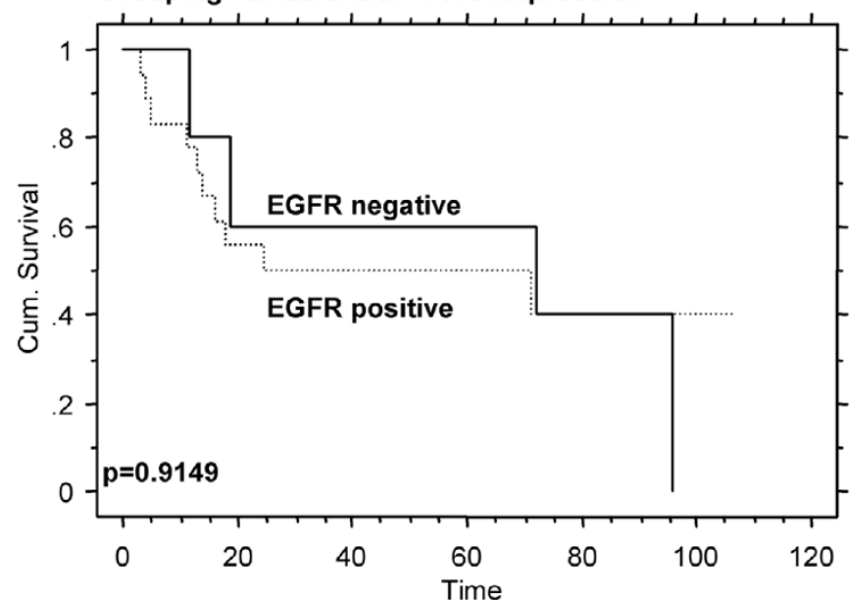

Kaplan-Meier Cum. Survival Plot for DFS

Censor Variable: Censor DFS

Grouping Variable: EGFR amplification (CISH)

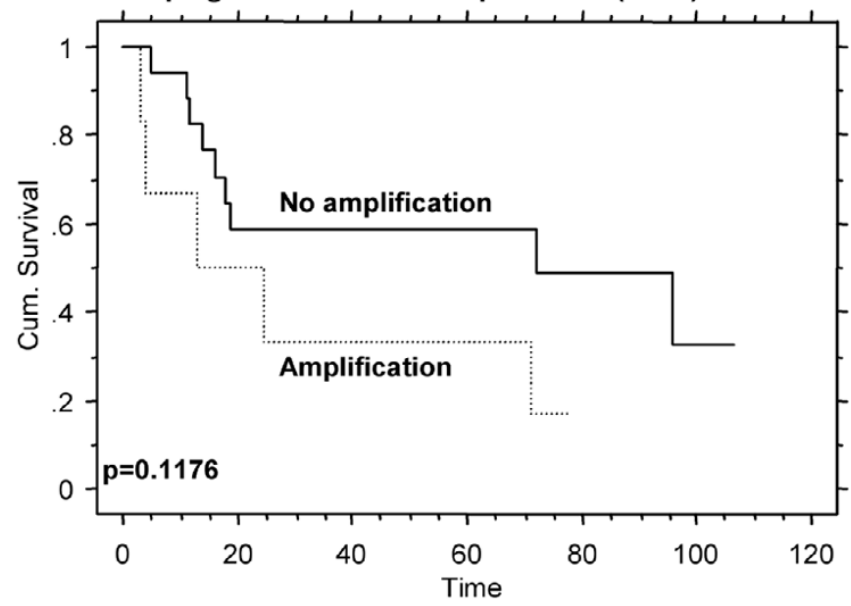

Kaplan-Meier Cum. Survival Plot for Overall survival; Censor Variable: Censor OS

Grouping Variable: EGFR overexpression

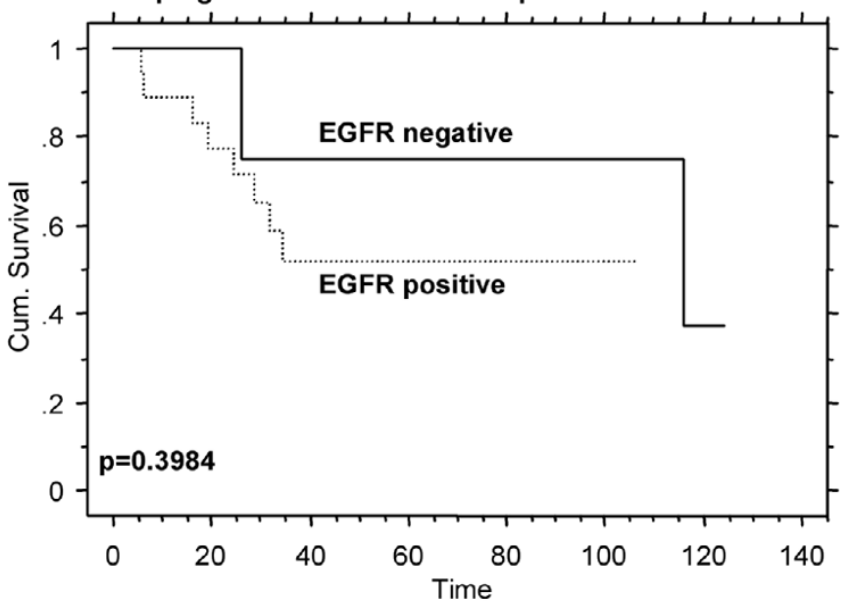

Kaplan-Meier Cum. Survival Plot for Overall survival; Censor Variable: Censor OS

Grouping Variable: EGFR amplification (CISH)

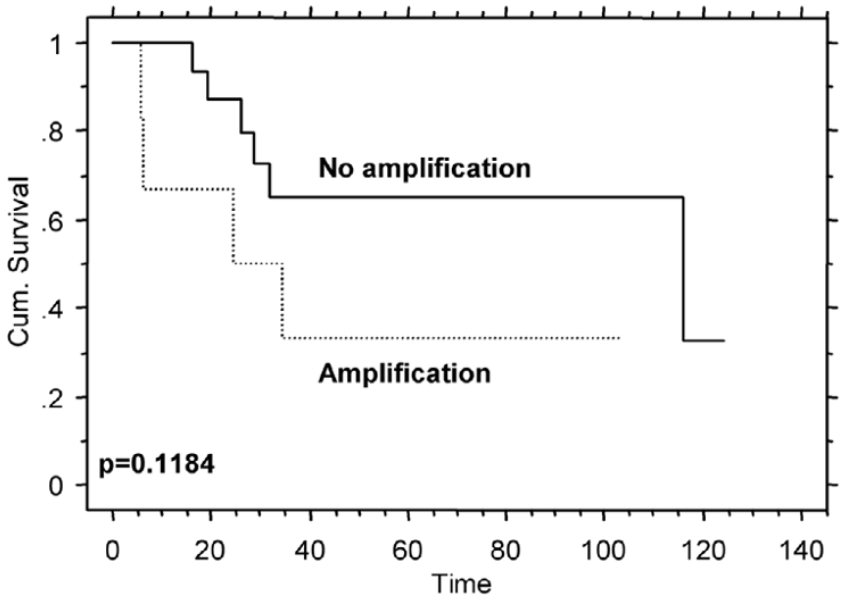

EGFR overexpression and amplification: prognostic impact on DFS and OS. CISH, chromogenic in situ hybridization; DFS, disease-free survival; EGFR, epidermal growth factor receptor; OS, overall survival.

showed no amplification. EGFR activating mutations have been described in lung cancer and in brain tumours, but these mutations have proven extremely rare in other types of cancer, including breast carcinomas [8,37]. However, Weber and coworkers [38] recently described EGFR missense mutations in sporadic and familial (BRCA1/BRCA2 related) breast cancer and demonstrated that these mutations are significantly more frequent in the latter. Therefore, further analysis of EGFR gene sequence in MBCs may explain the overexpression of EGFR in those cases lacking EGFR amplification.

An alternative mechanism for EGFR expression in MBC may be maintenance of a myoepithelial/basal phenotype. In fact, expression of EGFR is part of the definition of 'basal-like' tumours proposed by Nielsen and coworkers [39]. EGFR is consistently expressed in myoepithelial cells of the breast [40]. We $[26,41,42]$ and others [30,31,43-45] have demonstrated that the vast majority of MBCs consistently express basal/ myoepithelial markers. Furthermore, indirect evidence from a study using murine cell lines suggests that transformed myoepithelial cells may give rise to tumours with sarcomatous and carcinosarcomatous patterns, similar to those observed in spindle cell carcinomas and carcinomas with heterologous elements [46]. Therefore, one could speculate that overexpression of EGFR, without gene amplification, could simply reflect maintenance of the basal-like/myoepithelial phenotype of these lesions. Conversely, one cannot rule out that EGFR gene amplification is one of the genetic mechanisms whereby basal/myoepithelial differentiation pathways are activated in transformed luminal epithelial cells. 
In the present series, there was no association between EGFR overexpression and DFS or OS, whereas there was a trend toward shorter DFS and OS in patients with tumours exhibiting EGFR amplification. Based on our results, further studies analyzing the prognostic impact of EGFR amplification in a large cohort of MBCs are warranted.

The present study also confirms the results of previous analyses demonstrating lack of HER2 overexpression in MBCs $[12,47]$, suggesting that humanized monoclonal antibodies against HER2 play little or no role in the treatment of these lesions.

\section{Conclusion}

Although initial studies suggested that only tumours harbouring EGFR mutations would be sensitive to EGFR tyrosine kinase inhibitors, there are compelling data to suggest that tumours harbouring EGFR amplification may also respond well to these new agents [22]. Given that MBCs lack oestrogen receptor, show EGFR overexpression and harbour EGFR amplification in up to $28 \%$ of cases, and that some MBCs have proven refractory to standard types of treatment, the use of EGFR tyrosine kinase inhibitors may represent an alternative therapeutic regimen for patients with MBC. Further studies addressing the efficacy of EGFR inhibitors in this group of breast carcinomas are warranted.

\section{Competing interests}

The authors declare that they have no competing interests.

\section{Authors' contributions}

JSR-F drafted the manuscript and participated in the histological review, immunohistochemical analysis and study design. FM participated in the histological review, immunohistochemical and CISH analyses. SC carried out the CISH analysis. PTS helped to draft the manuscript and participated in the study design. DS and KS performed the immunohistochemical reactions. ML performed part of the CISH experiments. EMP and JN participated in the histological review. SRL and FCS conceived the study, participated in its design and coordination, and helped to draft the manuscript. FCS also participated in the histological review. All authors read and approved the final manuscript.

\section{Acknowledgements}

This study was supported by Breakthrough Breast Cancer and a grant Programa Operacional Ciência, Tecnologia e Inovação POCTI/CBO/ 45157/2002. JSR-F is partially supported by PhD Grant SFRH/BD/ 5386/2001 from the Fundação para a Ciência e a Tecnologia, Portugal.

\section{References}

1. Hynes NE, Lane HA: ERBB receptors and cancer: the complexity of targeted inhibitors. Nat Rev Cancer 2005, 5:341-354.

2. Suo Z, Risberg B, Kalsson MG, Willman K, Tierens A, Skovlund E, Nesland JM: EGFR family expression in breast carcinomas. $c-$ erbB-2 and c-erbB-4 receptors have different effects on survival. J Pathol 2002, 196:17-25.
3. Suo Z, Yang H, Mei Q, Skovlund E, Cui J, Nesland JM: Type 1 protein tyrosine kinases in Chinese breast carcinomas: a clinicopathologic study. Int J Surg Pathol 2001, 9:177-187.

4. Suo Z, Nesland JM: Phyllodes tumor of the breast: EGFR family expression and relation to clinicopathological features. Ultrastruct Pathol 2000, 24:371-381.

5. Suo Z, Emilsen E, Tveit KM, Nesland JM: Type 1 protein tyrosine kinases in benign and malignant breast lesions. Histopatho/ogy 1998, 33:514-521.

6. Abd El-Rehim DM, Pinder SE, Paish CE, Bell JA, Rampaul RS, Blamey RW, Robertson JF, Nicholson RI, Ellis IO: Expression and co-expression of the members of the epidermal growth factor receptor (EGFR) family in invasive breast carcinoma. $\mathrm{Br} J$ Cancer 2004, 91:1532-42.

7. DiGiovanna MP, Stern DF, Edgerton SM, Whalen SG, Moore D II, Thor AD: Relationship of epidermal growth factor receptor expression to ErbB-2 signaling activity and prognosis in breast cancer patients. J Clin Oncol 2005, 23:1152-1160.

8. Bhargava R, Gerald WL, Li AR, Pan Q, Lal P, Ladanyi M, Chen B: EGFR gene amplification in breast cancer: correlation with epidermal growth factor receptor mRNA and protein expression and HER-2 status and absence of EGFR-activating mutations. Mod Pathol 2005 in press.

9. Harris AL, Nicholson S, Sainsbury JR, Farndon J, Wright C: Epidermal growth factor receptors in breast cancer: association with early relapse and death, poor response to hormones and interactions with neu. J Steroid Biochem 1989, 34:123-131.

10. Tsutsui S, Kataoka A, Ohno S, Murakami S, Kinoshita J, Hachitanda Y: Prognostic and predictive value of epidermal growth factor receptor in recurrent breast cancer. Clin Cancer Res 2002, 8:3454-3460.

11. Walker RA, Dearing SJ: Expression of epidermal growth factor receptor mRNA and protein in primary breast carcinomas. Breast Cancer Res Treat 1999, 53:167-176.

12. Leibl S, Moinfar F: Metaplastic breast carcinomas are negative for Her-2 but frequently express EGFR (Her-1): potential relevance to adjuvant treatment with EGFR tyrosine kinase inhibitors? J Clin Pathol 2005, 58:700-704.

13. Giaccone G: Epidermal growth factor receptor inhibitors in the treatment of non-small-cell lung cancer. J Clin Oncol 2005, 23:3235-3242.

14. Baselga J, Arteaga CL: Critical update and emerging trends in epidermal growth factor receptor targeting in cancer. J Clin Oncol 2005, 23:2445-2459.

15. Pao W, Miller V, Zakowski M, Doherty J, Politi K, Sarkaria I, Singh $\mathrm{B}$, Heelan $\mathrm{R}$, Rusch V, Fulton L, et al.: EGF receptor gene mutations are common in lung cancers from 'never smokers' and are associated with sensitivity of tumors to gefitinib and erlotinib. Proc Natl Acad Sci USA 2004, 101:13306-13311.

16. Paez JG, Janne PA, Lee JC, Tracy S, Greulich H, Gabriel S, Herman P, Kaye FJ, Lindeman N, Boggon TJ, et al.: EGFR mutations in lung cancer: correlation with clinical response to gefitinib therapy. Science 2004, 304:1497-1500.

17. Lynch TJ, Bell DW, Sordella R, Gurubhagavatula S, Okimoto RA Brannigan BW, Harris PL, Haserlat SM, Supko JG, Haluska FG, et al:: Activating mutations in the epidermal growth factor receptor underlying responsiveness of non-small-cell lung cancer to gefitinib. N Engl J Med 2004, 350:2129-2139.

18. Marty M, Cognetti F, Maraninchi D, Snyder R, Mauriac L, TubianaHulin M, Chan S, Grimes D, Anton A, Lluch A, et al:: Efficacy and safety of trastuzumab combined with docetaxel in patients with human epidermal growth factor receptor 2-positive metastatic breast cancer administered as first-line treatment: results of a randomized phase II trial by the M77001 study group. J Clin Oncol 2005, 23:4265-4274.

19. Baselga J, Gianni L, Geyer C, Perez EA, Riva A, Jackisch C: Future options with trastuzumab for primary systemic and adjuvant therapy. Semin Oncol 2004, 31:51-57.

20. Fallon KB, Palmer CA, Roth KA, Nabors LB, Wang W, Carpenter $M$, Banerjee R, Forsyth $P$, Rich K, Perry A: Prognostic value of $1 p$, $19 q, 9 p, 10 q$, and EGFR-FISH analyses in recurrent oligodendrogliomas. I Neuropathol Exp Neurol 2004, 63:314-322.

21. Marquez A, Wu R, Zhao J, Tao J, Shi Z: Evaluation of epidermal growth factor receptor (EGFR) by chromogenic in situ hybridization (CISH) and immunohistochemistry (IHC) in archival gli- 
omas using bright-field microscopy. Diagn Mol Pathol 2004, 13:1-8.

22. Cappuzzo F, Hirsch FR, Rossi E, Bartolini S, Ceresoli GL, Bemis L, Haney J, Witta S, Danenberg K, Domenichini I, et al:: Epidermal growth factor receptor gene and protein and gefitinib sensitivity in non-small-cell lung cancer. J Natl Cancer Inst 2005, 97:643-655.

23. Takehana T, Kunitomo K, Suzuki S, Kono K, Fujii H, Matsumoto Y, Ooi $A$ : Expression of epidermal growth factor receptor in gastric carcinomas. Clin Gastroenterol Hepatol 2003 , 1:438-445.

24. Corzo C, Tusquets I, Salido M, Corominas JM, Bellet M, Suarez M, Baro T, Fabregat X, Serrano S, Sole F: Characterization of HER1 (c-erbB1) status in locally advanced breast cancer using fluorescence in situ hybridization and immunohistochemistry. Tumour Biol 2005, 26:25-30.

25. Al-Kuraya K, Schraml P, Torhorst J, Tapia C, Zaharieva B, Novotny $\mathrm{H}$, Spichtin H, Maurer R, Mirlacher M, Kochli O, et al.: Prognostic relevance of gene amplifications and coamplifications in breast cancer. Cancer Res 2004, 64:8534-8540.

26. Reis-Filho JS, Milanezi F, Simpson P, Fulford LG, Steele D, Nesland JM, Pereira EM, Lakhani SR, Schmitt FC: Are metaplastic breast carcinomas basal-like tumours? [abstract]. Mod Pathol 2005:48A.

27. Wargotz ES, Norris HJ: Metaplastic carcinomas of the breast: $\mathbf{V}$. Metaplastic carcinoma with osteoclastic giant cells. Hum Pathol 1990, 21:1142-1150.

28. Wargotz ES, Norris HJ: Metaplastic carcinomas of the breast. IV. Squamous cell carcinoma of ductal origin. Cancer 1990, 65:272-276.

29. Wargotz ES, Norris HJ: Metaplastic carcinomas of the breast. III. Carcinosarcoma. Cancer 1989, 64:1490-1499.

30. Wargotz ES, Deos PH, Norris HJ: Metaplastic carcinomas of the breast. II. Spindle cell carcinoma. Hum Pathol 1989, 20:732-740.

31. Wargotz ES, Norris HJ: Metaplastic carcinomas of the breast. I. Matrix-producing carcinoma. Hum Pathol 1989, 20:628-635.

32. Huvos AG, Lucas JC Jr, Foote FW Jr: Metaplastic breast carcinoma. Rare form of mammary cancer. NY State J Med 1973, 73:1078-1082

33. Oberman HA: Metaplastic carcinoma of the breast. A clinicopathologic study of 29 patients. Am J Surg Pathol 1987, 11:918-929.

34. Reis-Filho JS, Simpson PT, Jones C, Steele D, Mackay A, Iravani M, Fenwick K, Valgeirsson H, Lambros M, Ashworth A, et al.: Pleomorphic lobular carcinoma of the breast: role of comprehensive molecular pathology in characterization of an entity. J Pathol 2005, 207:1-13.

35. Isola J, Tanner M, Forsyth A, Cooke TG, Watters AD, Bartlett JM: Interlaboratory comparison of HER-2 oncogene amplification as detected by chromogenic and fluorescence in situ hybridization. Clin Cancer Res 2004, 10:4793-4798.

36. Bilous M, Dowsett M, Hanna W, Isola J, Lebeau A, Moreno A, Penault-Llorca F, Ruschoff J, Tomasic G, van de Vijver M: Current perspectives on HER2 testing: a review of national testing guidelines. Mod Pathol 2003, 16:173-182.

37. Lee JW, Soung YH, Kim SY, Park WS, Nam SW, Lee JY, Yoo NJ, Lee SH: Absence of EGFR mutation in the kinase domain in common human cancers besides non-small cell lung cancer. Int J Cancer 2005, 113:510-511.

38. Weber F, Fukino K, Sawada T, Williams N, Sweet K, Brena RM, Plass C, Caldes T, Mutter GL, Villalona-Calero MA, et al.: Variability in organ-specific EGFR mutational spectra in tumour epithelium and stroma may be the biological basis for differential responses to tyrosine kinase inhibitors. Br J Cancer 2005, 92:1922-1926.

39. Nielsen TO, Hsu FD, Jensen K, Cheang M, Karaca G, Hu Z, Hernandez-Boussard T, Livasy C, Cowan D, Dressler L, et al:: Immunohistochemical and clinical characterization of the basal-like subtype of invasive breast carcinoma. Clin Cancer Res 2004, 10:5367-5374.

40. Santini D, Ceccarelli C, Tardio ML, Taffurelli M, Marrano D: Immunocytochemical expression of epidermal growth factor receptor in myoepithelial cells of the breast. App/ Immunohistochem Mol Morphol 2002, 10:29-33.

41. Reis-Filho JS, Milanezi F, Paredes J, Silva P, Pereira EM, Maeda SA, de Carvalho LV, Schmitt FC: Novel and classic myoepithe- lial/stem cell markers in metaplastic carcinomas of the breast Appl Immunohistochem Mol Morphol 2003, 11:1-8.

42. Reis-Filho JS, Schmitt FC: p63 expression in sarcomatoid/ metaplastic carcinomas of the breast. Histopathology 2003, 42:94-95.

43. Leibl S, Gogg-Kammerer M, Sommersacher A, Denk H, Moinfar F: Metaplastic breast carcinomas: are they of myoepithelial differentiation?: immunohistochemical profile of the sarcomatoid subtype using novel myoepithelial markers. $\mathrm{Am} J$ Surg Pathol 2005, 29:347-353.

44. Dunne B, Lee AH, Pinder SE, Bell JA, Ellis IO: An immunohistochemical study of metaplastic spindle cell carcinoma, phyllodes tumor and fibromatosis of the breast. Hum Pathol 2003, 34:1009-1015.

45. Popnikolov NK, Ayala AG, Graves K, Gatalica Z: Benign myoepithelial tumors of the breast have immunophenotypic characteristics similar to metaplastic matrix-producing and spindle cell carcinomas. Am J Clin Pathol 2003, 120:161-167.

46. Sapino A, Papotti M, Sanfilippo B, Gugliotta P, Bussolati G: Tumor types derived from epithelial and myoepithelial cell lines of R3230AC rat mammary carcinoma. Cancer Res 1992, 52:1553-1560.

47. Barnes PJ, Boutilier R, Chiasson D, Rayson D: Metaplastic breast carcinoma: clinical-pathologic characteristics and HER2/neu expression. Breast Cancer Res Treat 2005, 91:173-178. 